\title{
PROBLBEM SOVING AND DECISION MAKING TRAINING FOR VILLAGE OFFICIALS TO IMPROVE THE QUALITY OF VILLAGE FINANCIAL MANAGEMENT IN CIAWI DISTRICT, BOGOR REGENCY
}

\author{
T. Herry Rachmatsyah and Harry Nenobais \\ Universitas Prof. Dr. Moestopo (Beragama), Indonesia. \\ herry.rachmatsyah@dsn.moestopo.ac.id
}

\begin{abstract}
Village finance must be managed in a transparent, accountable, and participatory manner, and carried out in an orderly and disciplined budget. For this purpose, village officials must have sufficient skills to be able to manage village finances based on good governance practices. In general, villages will experience various problems in each stage of the village financial management cycle and decisions must be made on these issues. To improve problem solving and decision-making skills, training was carried out using lecture, discussion, and simulation methods with training participants consisting of village heads, village secretaries, and heads of financial affairs or village treasurers. During the training, participants showed high attention to the material provided by the facilitators and actively participated in group discussions and simulations. The trainees also considered that the material presented was relevant to their needs and it was hoped that the knowledge gained could be applied to improve the quality of financial management in their respective villages.
\end{abstract}

Keywords: Problem Solving, Decision Making, Village Financial Management, Training

\section{INTRODUCTION}

Law Number 6 of 2014 concerning Village gives the village great authority to administer governance and carry out development in accordance with its own needs in order to improve the welfare of village communities. The independence of the village becomes the final goal desired to be achieved through the application of the law. It is hoped that various problems faced by Indonesia related to inequality in development, social inequality, poverty, and various other social and cultural problems can be reduced.

At present the village receives village funds allocated from the State Revenue and Expenditures Budget. The central government always allocates funds for the village every year. Village funds are transferred to the Regency/City Regional Revenue and Expenditures Budget and then transferred to the Village Revenue and Expenditures Budget. Funds are distributed in stages during the year to the Village Cash Account. In addition to village funds, based on Article 7 of Law Number 6 of 2014 concerning Village, villages also have Village Original Income and Transfer Income in the form of Village Fund Allocation; Part of Regency/City Tax and Retribution Results; and Financial Assistance from Provincial/Regency/City Regional Revenue and Expenditures Budget.

The large amount of the village budget needs to be balanced with adequate quality human resources. But this has become an obstacle in most villages in Indonesia. According to Deputi Bidang Pengawasan Penyelenggaraan Keuangan Daerah (2015), the village does not yet have procedures and facilities and infrastructure support in its financial management and the village community is not critical of the management of the Village Revenue and Expenditures Budget.

Based on Law Number 6 of 2014 concerning Village, villages must have good financial management. The village financial management cycle includes planning, implementation, administration, reporting, and accountability with a period of 1 fiscal year, starting from January 1 to December 31. In general, villages will experience various problems in each stage of the village financial management cycle and decisions must be made on these issues. Problems related to village financial management include the preparation of a Village Government Work Plan; preparation of Village Revenue and Expenditures Budget; collection of village revenue; take actions that result in expenditure on the burden of the Village Revenue and Expenditures Budget; reporting and accountability for the implementation of the Village Revenue and Expenditures Budget; verification of the Expenditures Budget Plan, evidence of receipt and expenditure of the Village Revenue and Expenditures Budget; and tax collection and deposit. Incorrect decisions on problems at one stage can interfere with the implementation of subsequent stages. Therefore village officials must have good problem solving and decision making skills.

Basically there are some important skills to solve problems. These skills consist of analytical skills, creative thinking, initiative, logical reasoning, persistence, teamwork, communication, persuasion, and negotiation (Joshi, 2017). The problem must be solved by making a decision. According to Adair, (2007), decision making consists of 5 stages, namely defining the objective, collecting relevant information, generating feasible options, making the decisions, and implementing and evaluating.

To help village officials to improve the quality of village financial management, Postgraduate Program Universitas Prof. Dr. Moestopo (Beragama) conducted community engagement activities in Ciawi District, Bogor Regency in 
the form of training on one of the important aspects of village financial management, namely problem solving and decision making.

\section{IMPLEMENTATION METHOD}

Community engagement activities were carried out in the form of training. The first meeting in the form of the opening of the training activities was held at the Ciawi District Office Meeting Hall, Bogor Regency on June 2, 2018. Furthermore, the training was held as many as 4 meetings held every weekend (Saturday and Sunday) on the second and fourth week of June 2018 with a duration of 3 hours for each meeting (9.00-12.00).

Participants involved in the training were 39 village officials from all villages in Ciawi District, Bogor Regency (Banjar Sari, Banjar Wangi, Banjar Waru, Dam, Bitung Sari, Bojong Murni, Ciawi, Cibedug, Cileungsi, Citapen, Jambu Luwuk, Pandansari, and Teluk Pinang) consisting of 13 village heads, 13 village secretaries, and 13 heads of financial affairs or village treasurers. There were 4 training facilitators consisting of 2 lecturers assisted by 2 students from Postgraduate Program Universitas Prof. Dr. Moestopo (Beragama).

The training was conducted using lecture, discussion and simulation methods. The lecture was conducted by conveying knowledge about problem solving and decision making using whiteboard, projectors, and loudspeakers to the trainees. The knowledge conveyed consists of problem solving skills and decision making approaches. Discussion was very closely related to solving problems. Through discussion it was hoped that training participants could think critically, express their opinions freely, and be able to contribute to solving the problems at hand. Simulations were carried out using real cases of village financial management experienced by many villages including those actually experienced by the trainees themselves. Through simulations, training participants were expected to be able to apply the knowledge they have acquired or have previously learned and help trainees to improve their cognitive, affective, and psychomotor abilities.

\section{RESULT AND DISCUSSION}

Community engagement activities were carried out in 3 stages, namely preparation, implementation and evaluation. In the preparation stage, the organizing committee visited the Ciawi District Office to determine the training needs required by village officials, determined the agreed time for activities, arranged for permission to conduct activities, prepared training materials and equipment, and made invitations to training participants and related parties.

Community engagement activities were officially opened by Ciawi District Head and the Director of Postgraduate Program Universitas Prof. Dr. Moestopo (Beragama) at the Ciawi District Office Meeting Hall on June 2, 2018. At the opening ceremony the aims and objectives of the activity were presented, namely carrying out community engagement in the form of training to help village officials improve the quality of village financial management. The training was held in 4 meetings every weekend on the second and fourth week of June 2018 with a duration of 3 hours for each meeting.

At the first meeting (Saturday, June 9, 2018), the material presented was about various regulations related to village financial management (Law Number 6 of 2014 concerning Village, Government Regulation Number 43 of 2014 concerning Village, Government Regulation Number 60 of 2014 concerning Village Funds Sourced from the State Revenue and Expenditures Budget, and Regulation of the Minister of Home Affairs Number 113 of 2014 concerning Village Financial Management); Village Financial Management; Village Government Financial Organization; Village Financial Planning and Budgeting; Implementation of Village Revenue and Expenditures Budget, Village Financial Administration; and Village Financial Reporting and Accountability.

At the second meeting (Sunday, June 10,2018), the material presented was about problem solving (goal of problem solving, problem solving skills, problem solving process, stages of problem solving, and problem solving methods).

At the third meeting (Saturday, June 23, 2018) the material presented was about decision making (characteristics, scope, goals, types, processes, and turning decisions into effective actions). The training at the first, second, and third meeting prioritizes lectures and discussions because the training participants based on the results of the discussion before the training have low knowledge and insights about the material presented. At the fourth meeting (Sunday, June 24, 2018) a simulation was carried out using real cases of village financial management experienced by many villages including those actually experienced by the training participants themselves. These cases included preparation of the Village Government Work Plan; preparation of Village Revenue and Expenditures Budget; collection of village revenue; actions that result in expenditure on the burden of the Village Revenue and Expenditures Budget; reporting and accountability for the implementation of the Village Revenue and Expenditures Budget; verification of the Expenditures Budget Plan, evidence of receipt and expenditure of the Village Revenue and Expenditures Budget; and tax collection and deposit. In the simulation, the training participants were divided into 3 groups, each consisting of 13 people. Each group applied the knowledge that had been obtained in solving a problem that was used as a case to arrive at a decision that was considered the best. Decisions made were then presented to get responses from participants from other groups. During the simulation the training facilitators provided input and direction and provided an explanation if there were questions from the training participants. 
Based on observations made during the training activities, the participants generally showed high attention to the materials delivered by the facilitators, actively asked questions and expressed opinions about things they experienced related to village fund management, and showed a high level of participation when involved in group simulations to discuss cases made as group assignments.

Evaluation was carried out at the end of the activity by distributing questionnaires to the training participants to find out their assessment of the training activities that had been followed. In general, the evaluation was very good because on average the score was $93.3 \%$ as can be seen in the Table 1 . Learning methods and consumption were the two aspects of activities that get the lowest assessment from the training participants. Both aspects would be input for improvement for further training activities.

Table 1. Activity Evaluation Results

\begin{tabular}{|c|l|c|c|}
\hline \multirow{2}{*}{ Number } & \multicolumn{1}{|c|}{ Statement } & \multicolumn{2}{c|}{ Opinion (\%) } \\
\cline { 3 - 4 } & & \multicolumn{1}{|c|}{ Yes } & No \\
\hline 1 & $\begin{array}{l}\text { Training material was relevant to the needs of the } \\
\text { participants. }\end{array}$ & 100 & 0 \\
\hline 2 & Facilitators mastered training material well. & 94,9 & 5,1 \\
\hline 3 & Training equipment was well available. & 94,9 & 5.1 \\
\hline 4 & Training started and ended on time. & 100 & 0 \\
\hline 5 & Learning method used was appropriate. & 84,6 & 15,4 \\
\hline 6 & $\begin{array}{l}\text { Complete facilities and infrastructure for activities } \\
\text { were available. }\end{array}$ & 92,3 & 7,7 \\
\hline 7 & $\begin{array}{l}\text { Cleanliness of the place of activity was maintained } \\
\text { well. }\end{array}$ & 97,4 & 2,6 \\
\hline 8 & Proper consumption was provided. & 82,1 & 17,9 \\
\hline & Average & 93,3 & 6,7 \\
\hline
\end{tabular}

\section{CONCLUSION}

The large amount of the village budget needs to be balanced with adequate quality human resources. Community engagement activities carried out by Postgraduate Program universitas Prof. Dr. Moestopo (Beragama) aims to improve the quality of human resources managing village finances, namely village officials (village heads, village secretaries, and heads of financial affairs or village treasurers). The activity was carried out in the form of training which was divided into 4 meetings with material on various regulations related to village financial management, problem solving, and decision making. The learning methods used were lectures, discussions, and simulations. Based on observations during the activities and analysis of the questionnaire distributed after the activity, it could be concluded that the training carried out received positive responses from the training participants. The high level of attendance and participation in each meeting and the ability to present decisions taken in group simulations showed that the objectives of the training activities were achieved. The training participants' skills in solving problems and making decisions improved and were expected to improve the quality of village financial management in their respective villages.

Training on problem solving and decision making in village financial management can be continued in other locations. However, there are still aspects that need to be considered in organizing future training activities, namely learning and consumption methods. In addition to lectures, discussions and simulations, other learning methods can be used such as demonstrations, laboratories, and field trips. Satisfaction with consumption can be improved by adjusting the dishes served to the tastes or desires of the majority of training participants. Therefore the organizing committee should provide various alternative dishes to be selected by training participants. In addition, there are also many other aspects related to village financial management that can be used as objects of subsequent training activities, for example financial accounting, financial information systems, and financial audits.

\section{REFERENCES}

Adair, John. (2007). Decision making and problem solving strategies. Kogan Page, London

Deputi Bidang Pengawasan Penyelenggaraan Keuangan Daerah. (2015). Petunjuk pelaksanaan bimbingan \& konsultasi pengelolaan keuangan desa. Badan Pengawasan Keuangan dan Pembangunan, Jakarta Joshi, Manmohan. (2017). Soft skills. Bookboon, London

Regulation of the minister of home affairs number 113 of 2014 concerning village financial management.

Government regulation number 43 of 2014 concerning village.

Government regulation number 60 of 2014 concerning village funds sourced from the state revenue and expenditures budget.

Law number 6 of 2014 concerning village.

Suraya, Ponco Budi Sulistyo. (2019). Sosialiasi Indentifikasi Peluang Usaha Kelautan dan Perikanan di Pesisir Pantai Sawarna, Lebak Banten. Jurnal Abdi Moestopo, 2(2), 30-37. 